\title{
Composting of EFB and POME Using a Step-Feeding Strategy in a Rotary Drum Reactor: The Effect of Active Aeration and Mixing Ratio on Composting Performance
}

\author{
Rosnani Alkarimiah ${ }^{1 *}$, Fatihah Suja ${ }^{2}$ \\ ${ }^{1}$ School of Civil Engineering, Universiti Sains Malaysia, Pulau Pinang, Malaysia \\ ${ }^{2}$ Faculty of Engineering and Built Environment, Universiti Kebangsaan Malaysia, Selangor, Malaysia
}

Received: 7 May 2019

Accepted: 7 July 2019

\begin{abstract}
In this study, the effect of active aeration and the different mix ratio has been carried out in the rotary drum reactor by adapting step-feeding strategy. The main biowaste used is empty fruit bunches (EFB), palm oil mill effluent (POME) sludge and recycled compost. In the composting process, 4 experimental runs were carried out. Namely, as Mix 1 on Run A and Run B using the same mix ratio of $10 \mathrm{~kg}$ EFB:1 $\mathrm{kg}$ POME sludge:5 kg recycle compost. For Run A no active aeration is used, while Run B uses active aeration. While Run C (Mix 2) and Run D (Mix 3) are a study to determine the most effective mix for obtaining quality compost with the optimum percentage of moisture content. Run C using a mix ratio of $5 \mathrm{~kg}$ EFB:0.5 kg POME sludge: $2.5 \mathrm{~kg}$ recycled compost. Run D using a mix ratio of $5 \mathrm{~kg}$ EFB:2.0 $\mathrm{kg}$ POME sludge:0.5 recycled compost. The moisture content of Phase 3 in the four runs is within the range of 58.6-70\%. Final C/N ratios for Run A, Run B, Run C and Run $\mathrm{D}$ are $20.61,17.54,13.06$ and 14.51 respectively. The highest temperature achieved is $55^{\circ} \mathrm{C}$ (Run A), $45.2^{\circ} \mathrm{C}$ (Run B), $43^{\circ} \mathrm{C}$ (Run C) and $53.3^{\circ} \mathrm{C}$ (Run D). Continuous aeration is ineffective for achieving a thermophilic temperature in the drum. Besides, the mixed ratio of fresh $\mathrm{EFB}$, recycled compost and POME sludge plays an important role in achieving optimum composting conditions in terms of C:N ratio and moisture content percentage.
\end{abstract}

Keywords: active aeration, mixing ratio, step-feeding strategy, rotary drum reactor

\section{Introduction}

Composting is the process of biological decomposition of organic matter under controlled conditions, in aerobic

*e-mail: cerosnani@usm.my conditions to produce stable humus products [1]. controlled terms indicate that this process is managed or optimized to achieve the desired objectives. Composting can occur in many ways using a variety of materials, methods, equipment and operating scales. Stability and maturity are indicators commonly used to refer to the quality of compost. Co-composting is termed as an aerobic deterioration of controlled organic waste 
that uses more than one ingredient (such as a mixture of POME sludge and organic solid waste) [2]. Palm oil mill effluent (POME) sludges have high moisture content and organic content, while biodegradable solid waste such as EFB contains high-carbon content and has properties of adhesives that allow air to flow and circulate. Empty fruit bunches (EFBs) are the ideal raw materials for recycling as they are produced in large quantities in the local area, particularly in Malaysia. Up to 2018, an area of 5.85 million hectares of land in Malaysia under the cultivation of oil palm and 82 million tons of biomass were produced. Statistics from National Biomass Strategy Blueprints shows ahead in 2020, and Malaysia's palm oil industry is expected to generate about 100 million tons of biomass. This will give a challenge to the industry and researchers to utilize the biomass and change it into value-added products. According to [3], the normal use rate of EFB is 40-70 tons per hectare. Research on the decomposition characteristics of EFB during the composting process was carried out by many researchers until this recent year [4-9]. The main constituents in EFB contain 45$50 \%$ cellulose, $25-35 \%$ hemicellulose and 19-20\% lignin [10-12]. High lignin, hemicellulose and cellulose content in EFB fibers causes it to be a difficult material to degrade.

The use of technology creates EFB's value-added products that successfully produce products such as ethanol, methane recovery, briquette products, heat and energy combination plants, compost products, medium-density fiberglass products and paper products [13]. However, composting has been recognized by agronomists in that using EFB as composting material can reduce by $50-75 \%$ the total volume of EFB generated from the extraction process of palm oil. EFB composting materials are also suitable for horticulture and landscaping. This study generally reflects a more integrated and comprehensive solution to EFB and POME management through composting. It also aims to achieve the goal of zero-waste management, which is being upgraded to be achieved by most industries - especially the palm oil industry in Malaysia. Success in developing new composting technologies is crucial and has a significant impact on the country's agricultural sector in terms of increasing productivity and farm acquisitions while at the same time saving costs from importing chemical fertilizers. It is believed that the rotary drum reactor type composting technology can play an important role in different types of organic waste management to stabilize the compost as rapidly as possible [14]. The use of this reactor is one step that reduces the dumping of organic waste at the palm oil mill. This is because the composting process in the reactor is taking a faster time than the windrow composting system. The organic waste can be decomposed effectively in a rotary drum composter within a composting period of 2 to 3 weeks [15]. Therefore, this study will focus on the rotary drum reactor operation study to achieve an optimum level of composting process, which the effect of active aeration and different mixing ratio by using organic waste EFB and POME. The present studies evaluate the dynamics of composting in terms of $\mathrm{C} / \mathrm{N}$ ratio (change of TOC and TKN), moisture content and temperature.

\section{Material and Methods}

The main organic waste components used in this study are palm oil mill effluent (POME) sludge and palm empty fruit bunches (EFB). The empty fruit bunches (EFB) used in this study comprise fresh palm oil EFB. Fresh fruit bunches (EFB) used for compost materials were obtained from the Sri Ulu Langat Palm Oil Processing Factory in Dengkil, Selangor. The EFB was shredded in the factory. The estimated length of each shredded EFB is $3-13 \mathrm{~cm}$. The moisture content of EFB taken was about 24\%, while POME sludge for this study is gathered from conventional aerobic treatment plant. Raw waste component characteristics are shown in Table 1. The overall composting activity in this study was carried out using a rotary drum reactor made from stainless steel measuring $3 \mathrm{~m}$ long with a diameter of $0.6 \mathrm{~m}$. The reactor works with the support of a 3-phase motor system with a maximum 2 rotations per minute. The reactor in this study operated 8 hours a day. Rotation frequency for this study was limited to only 6 rotations per 1 hour of operating time.

\section{Study Procedures}

There are 3 different mixture with 4 runs studied in this composting process as shown in Table 2. For Mixture 1 at Run A and Run B, composting is done by studying the effectiveness of activated aeration on compost waste in the rotary drum reactor by using the at the same rate of compost mixture ratio. For Run B, minimum aeration rate has been applied to the rotary drum reactor, i.e., $300 \mathrm{~m}^{3}$ air/volatile material/day. The volume of air that needs to be supplied to

Table 1. Raw waste component characteristics.

\begin{tabular}{|c|c|c|c|}
\hline Parameter & Empty Fruit Bunches (EFB) & Aerobic Palm Oil Mill Effluent (POME) Sludge & Recycle Compost \\
\hline Moisture Content, $\%$ & $24 \pm 5.8$ & $94 \pm 3.3$ & $80 \pm 0.5$ \\
\hline $\mathrm{pH}$ & $6.7 \pm 0.2$ & $7.5 \pm 0.5$ & $7.59 \pm 0.3$ \\
\hline $\mathrm{C} / \mathrm{N}$ & 58.9 & 8.3 & 10.3 \\
\hline
\end{tabular}


Table 2. Mixing ratios of EFB, POME sludge and recycled compost on each mixture.

\begin{tabular}{|c|c|c|c|c|c|}
\hline Mixture & Run & EFB $(\mathrm{kg})$ & POME Sludge (kg) & Recyle Compost (kg) & Mixture ratio \\
\hline \multirow{2}{*}{ Mixture 1 } & A & 10 & 1 & 5 & $10: 1: 5$ \\
\cline { 2 - 6 } & B & 10 & 1 & 5 & $10: 1: 5$ \\
\hline Mixture 2 & C & 5 & 0.5 & 2.5 & $5: 0.5: 2.5$ \\
\hline Mixture 3 & D & 5 & 2.0 & 0.5 & $5: 2: 0.5$ \\
\hline
\end{tabular}

the reactor is $35.1 \mathrm{~m}^{3}$. The amount of air compressor capacity to supply the air in this study is $122 \mathrm{~L} / \mathrm{min}$. The composting process of Run B with activated aeration is carried out for 20 days, then the air supply rate to be supplied to the rotary drum reactor for 1 day is about 14 minutes. The air was supplied continuously for 14 minutes/day to the compost material in the reactor throughout the composting process in Run B, whereas for Mixed 2 Run C and Mixed 3 Run D, different mixing ratios were used to obtain optimum percentage moisture content and temperature. Recycle compost being used in this study was obtained from the previous old EFB and POME compost. EFB, POME sludges and recycled compost are mixed manually according to the daily mixing ratio at each run before the mixtures are added to a rotary drum reactor. The purpose of composting materials is to mix them manually before adding them to a reactor in order to ensure the mixture is well mixed and homogeneous before undergoing the composting process.

The process of adding compost materials of each mixture into a rotary drum reactor are done on a daily basis according to the stated ratio. Overall, $150 \mathrm{~kg}$ of EFB fiber (the result of a mixture of fresh EFB fiber and recycling) and $30 \mathrm{~kg}$ of POME sludge have been used for each mixture in this optimization phase. From the observations on Mixture 1, Run A and Run B, the compost product reached the outlet section on day 11 because the volume of the rotary drum is only able to accommodate $150 \mathrm{~kg}$ of fiber material at any one time. For Mixtures 2 and 3, the compost product resulted in the outlet section on day 16 . The compost output from the outlet section was then be restored into the feeding section until the composting process was completed.

\section{Parameter Analysis Method}

To produce stable and high-quality compost results, some parameters affecting this process such as temperature, $\mathrm{C} / \mathrm{N}$ ratio and moisture content have been monitored. In this study, the monitoring process was carried out throughout the composting process until it reached the maturation stage. Temperature readings are monitored daily. Meanwhile, moisture content reading was measured twice a week to maintain moisture in composting materials, with the monitoring of the $\mathrm{C} / \mathrm{N}$ reading ratio taken every 3 days. According to [16], the biological decomposition process is considered complete and the mature compost is produced when the compost temperature is stable and reaches ambient temperature. Therefore, the composting process in this study is only monitored until the day when the temperature has begun to show a decline and is stable.

\section{Results and Discussion}

\section{Effect of Active Aeration and Mixing Ratio on Moisture Content}

The optimum moisture content in the composting process depends on the specific physicochemical properties and biological features of the materials being composted [17]. Moisture content affects microbial activity, as well as the physical structure, in the composting process, and thus has a central influence on the biodegradation of organic materials [18]. Previously reported optimum moisture contents for composting range is between $50 \%$ to $70 \%$ [19-20]. Excessive moisture content invites various problems such as anaerobic conditions in compost heap and loss of nutrients and pathogens in the form of leachate. Fig. 1 shows the percentage change in the moisture content of Run A and Run B in Mixture 1 with the effect of active aeration. In the early stage of the Run A study, moisture content was low at $24.36 \%$. But from day 2 , the percentage of moisture content increased by $50.28 \%$. Low initial moisture content is due to the mixtures of organic compounds that are still in uniform condition. In the early stages of the composting process, the moisture content of the organic compound showed a fluctuation trend, with a minimum value of $35 \%$ on day 10. However, this value is seen to be more stable when the composting process is over. The final value of moisture content in Run A was $58.6 \%$. Similar trends are seen in Run B process composting. The initial value of the Run B process is $32 \%$. However, from the $3 \mathrm{rd}$ day, the moisture content of the contents increased to $48.79 \%$. The highest moisture content in Run B was $63.29 \%$ on day 11 . However, this moisture content returns to a decline and stabilizes with a final moisture content of $58.66 \%$. From the graph, it can also be seen that the active aeration in Run B affects the stability of moisture content in composting material throughout the composting process. However, from the results obtained in the composting process of Run A and Run B, it is 


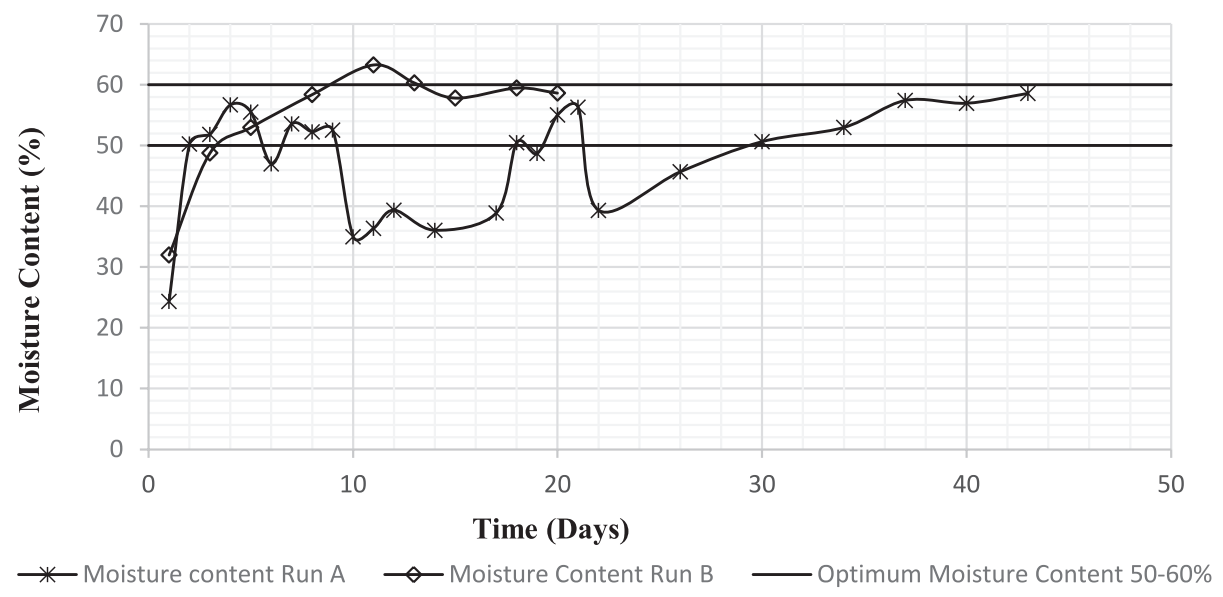

Fig. 1. Profiles of composting moisture content on Run A and Run B without active aeration and with active aeration.

found that the final percentage of moisture content is within the optimal range even at the start of the process, when the content of the two mixtures is relatively low.

Meanwhile, Fig. 2 shows the percentage change in the moisture content of Run C and Run D. On Run C, the initial value of composting mixture was 59.22\%, and on day 4 the percentage of moisture content soared to $74.92 \%$. The trend of moisture content fluctuations is seen after day 4 , with the final value obtained on day 23 of $70 \%$. The moisture content of Run $\mathrm{C}$ was high compared to Run A and Run B. This high moisture content may be due to a mixture of non-uniform composting ingredients and the percentage of mixtures in this run using a recycle compost of $2.5 \mathrm{~kg}$ per EFB mixture. This affects the moisture content of compost ingredients in Run C. According to [21], The initial moisture level is dependent on the concentration of the compost mixture and material. For the percentage of moisture content of Run D, the initial value obtained was $61.25 \%$. After 4 days of composting process, the value of moisture content showed a slight decrease to $53.3 \%$. The moisture content of Run D is more uniform in the range of moisture content of $59-63 \%$. The value of moisture content in Run D was seen to be more uniform and less compared to Run C compost. This was due to the mixed ratio of Run D being modified to achieve the optimum value of the moisture content in the composting process.

\section{Effect of Active Aeration and Mixing Ratio on $\mathrm{C} / \mathrm{N}$ Ratio}

Two of the most important nutrient parameters in the composting process are carbon and nutrients. Carbon nitrogen ratio during composting affects the process and subsequently the resulting product. Previous studies have shown that the optimum $\mathrm{C} / \mathrm{N}$ ratio for composting is between 20-25 [22-23] and 25-30 [24]. However, $\mathrm{C} / \mathrm{N}$ ratio of $10-15$ is typically recognized as a value representing the humic acid formation and improved stability of a compost [25].

Fig. 3 shows the change pattern of $\mathrm{C} / \mathrm{N}$ ratio on Run $\mathrm{A}$ and Run B for Mixture 1, with active aeration effect from the beginning of the composting process carried out until the maturity phase. In the early stages of the study on Phase 3 , the total $\mathrm{C} / \mathrm{N}$ ratio at Run $\mathrm{A}$ was 39.37 with a carbon value of $\mathrm{C}(53.25 \%)$ and nitrogen (N) with a value of $1.35 \%$. Final $\mathrm{C} / \mathrm{N}$ ratio for Run

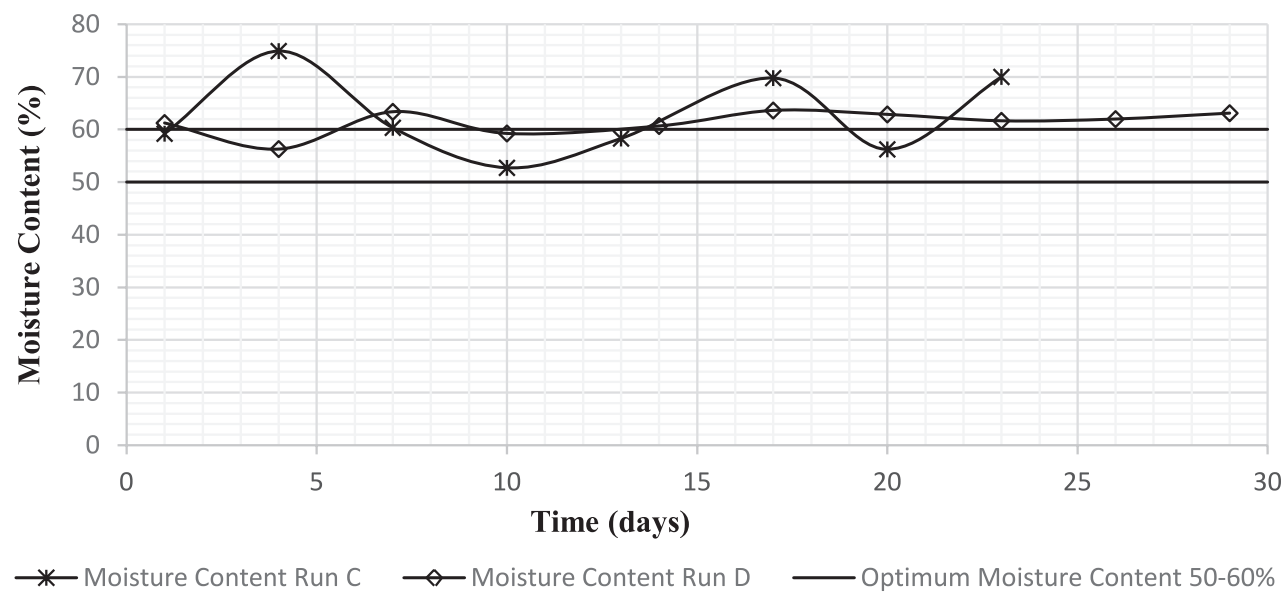

Fig. 2. Profiles of composting moisture content on Run C and Run D with different mixing ratios. 


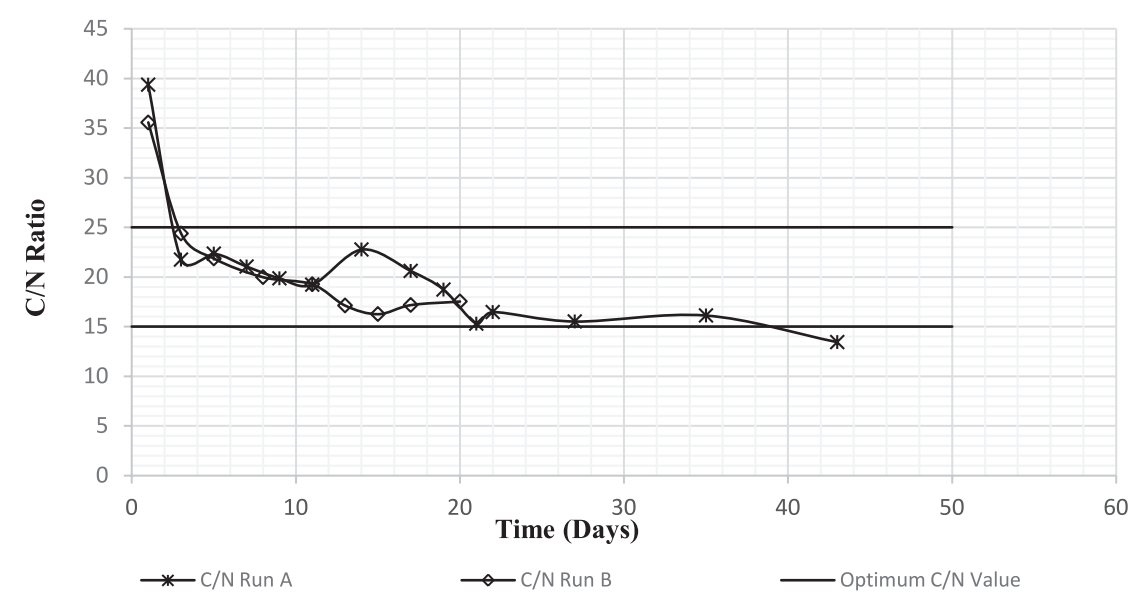

Fig. 3. Change in $\mathrm{C} / \mathrm{N}$ ratio on Run $\mathrm{A}$ and Run $\mathrm{B}$.

$\mathrm{A}$ is 13.44 with value of $\mathrm{C}$ of $38.47 \%$ and $\mathrm{N}$ value of $2.86 \%$. Meanwhile, the initial value of $\mathrm{C} / \mathrm{N}$ on Run $\mathrm{B}$ in the record with a value of 35.56 (52.01\% of carbon) decreased to 17.54 with a $\mathrm{C}$ value of $38.92 \%$ and $\mathrm{N}$ value of $2.22 \%$. The value of the $\mathrm{C} / \mathrm{N}$ ratio at the early stage of the study was high because the high carbon content of EFB fiber (in the form of lignin, cellulose and hemicellulose) increased the value of $\mathrm{C} / \mathrm{N}$ ratio in compost [26]. From Fig. 3, the value of $\mathrm{C} / \mathrm{N}$ ratio decreases steadily on both runs. This patent specifies $\mathrm{C}$ utilization by the microorganisms as it serves as a primary energy source [27]. In terms of $\mathrm{C} / \mathrm{N}$ ratio,

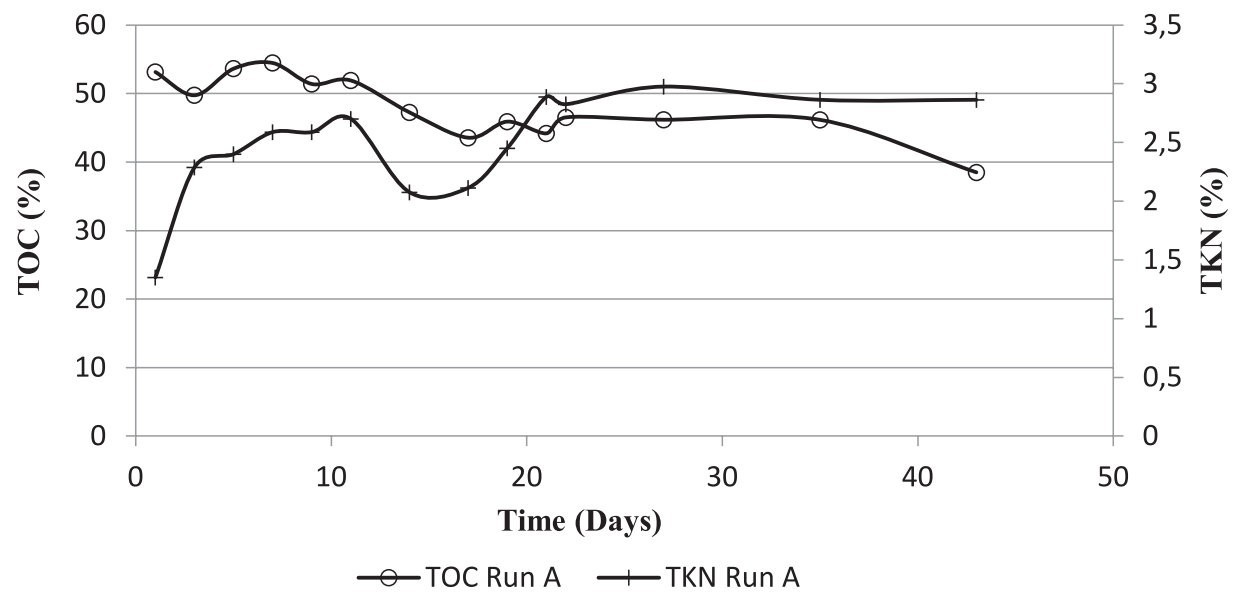

Fig. 4. TOC and TKN changes to time in mixture 1 in Run A.

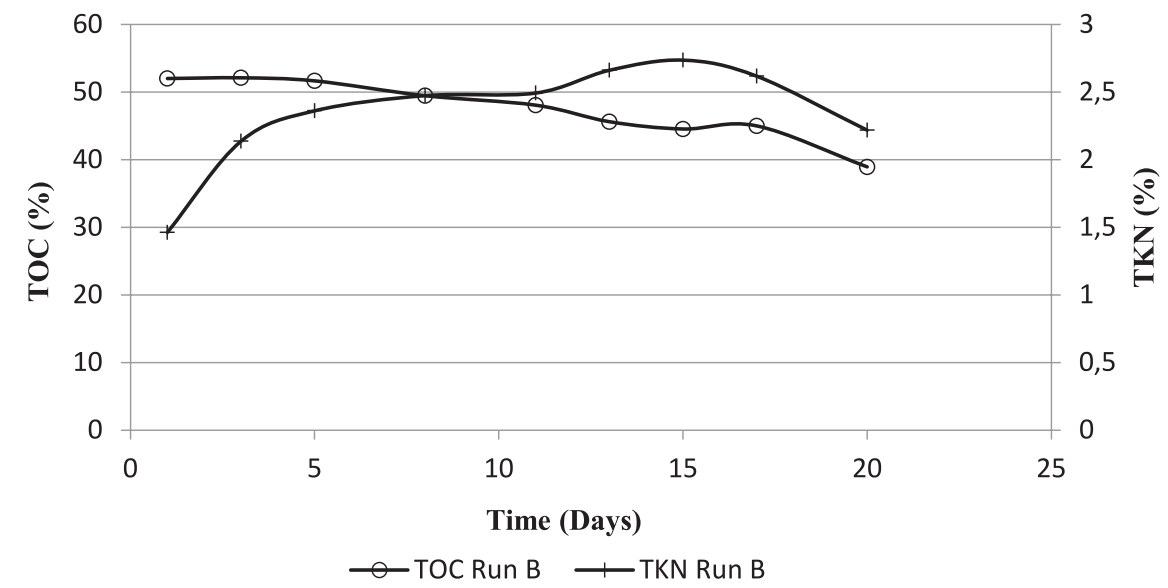

Fig. 5. TOC and TKN changes to time in Mixture 1 in Run B. 
Table 3. Univariate test analysis results for $\mathrm{C} / \mathrm{N}$ ratio on Run A and Run B.

\begin{tabular}{|c|c|c|c|c|c|}
\hline Parameter & Sum of squares & Degrees of freedom & Mean square & F-value & $p$-value \\
\hline Standard error of estimate & 10.581 & 1 & 10.581 & 28.556 & 0.000 \\
\hline Standard error value & 17.045 & 46 & 0.371 & & \\
\hline
\end{tabular}

active aeration does not make much difference to the composting process. However, higher temperature resulted in lower $\mathrm{C}$ consumption, possibly due to the destruction of certain species of microorganisms which are involves in the composting process [28]. The nitrogen $(\mathrm{N})$ range of compost materials for both runs is $1.35-2.86 \%$. An increase in $\mathrm{N}$ content may be due to the mineralization and active microbial cellulolytic degradation of complicated molecules in which it releases $\mathrm{N}$ and other ions into the compost [27]. The final value of nitrogen in Run A much higher than final $\mathrm{N}$ in Run $\mathrm{B}$, in which the value of final for both runs are $2.86 \%$ and $2.22 \%$ respectively. This may be due of the reaction time for Run A being much longer than Run B (43 days for Run A and 20 days for Run B). [27] in their study also stated that $\mathrm{N}$ content is greatly affected by reaction time. Figs 4 and 5 show the change in the value of total organic carbon (TOC) and total Kjedahl nitrogen (TKN) in the composting process of Runs $A$ and $\mathrm{B}$.
Table 3 shows the results of the univariate test for $\mathrm{C} / \mathrm{N}$ ratio data on Run $\mathrm{A}$ and Run $\mathrm{B}$. From the results, there is a significant difference in $\mathrm{C} / \mathrm{N}$ ratio in both runs, with $\mathrm{p}$ value of $0.000(\mathrm{p}<0.005)$ and $\mathrm{F}$ of 28.556 . The mean value obtained is 20.231 for Run $\mathrm{A}$ and 21.033 for Run B. Based on the mean value, it can be observed that the ratio of $\mathrm{C} / \mathrm{N}$ for composting through the composting process on Run A (without active aeration) and Run B (with active aeration) is within the optimum range in the composting process of 20-25:1.

Besides, the initial $\mathrm{C} / \mathrm{N}$ ratio of Run $\mathrm{C}$ was recorded at a value of 32.26 while the carbon value obtained was $54.24 \%$. There is a trend fluctuation in the middle of the process on Run $\mathrm{C}$. However, the final $\mathrm{C} / \mathrm{N}$ ratio obtained on Run $\mathrm{C}$ is 13.06 with a carbon value of $38.54 \%$. On Run C, the value of $\mathrm{N}$ obtained is within the range of $1.68-3.47 \%$. Fig. 6 shows the change of $\mathrm{C} / \mathrm{N}$ ratio throughout the composting process on Run $\mathrm{C}$ and Run D. Throughout the Run C composting process, there is a uniform reduction in carbon content

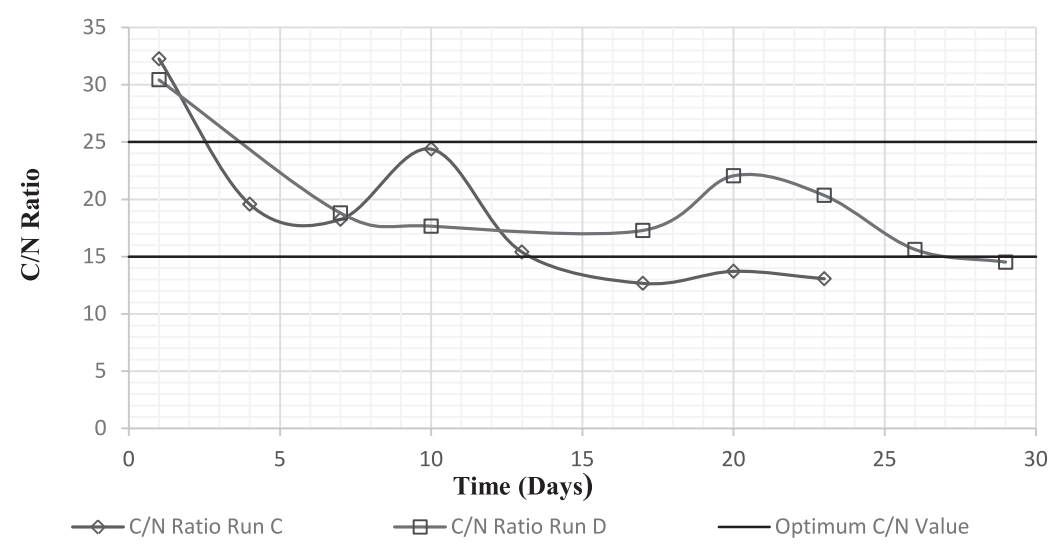

Fig. 6. Change in $\mathrm{C} / \mathrm{N}$ ratio on Run $\mathrm{C}$ and Run D.

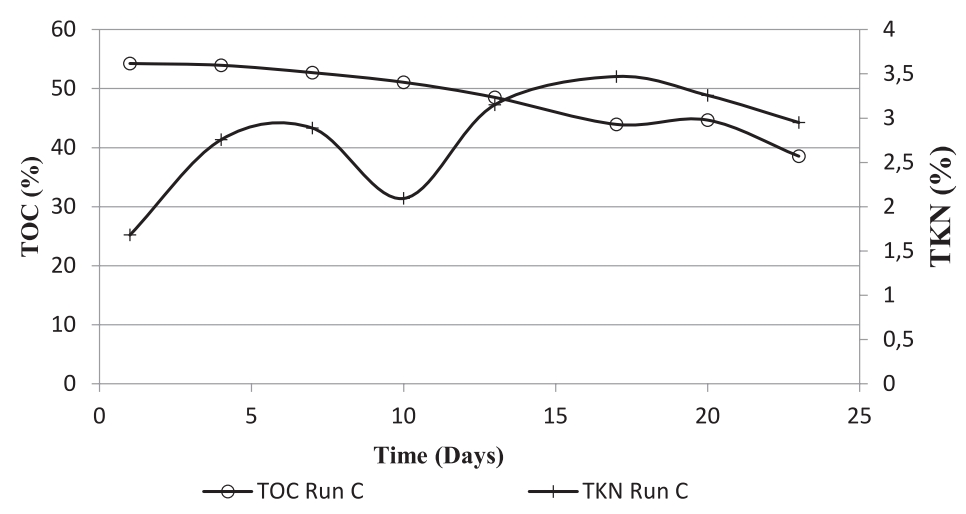

Fig. 7. TOC and TKN changes to time on Run C. 


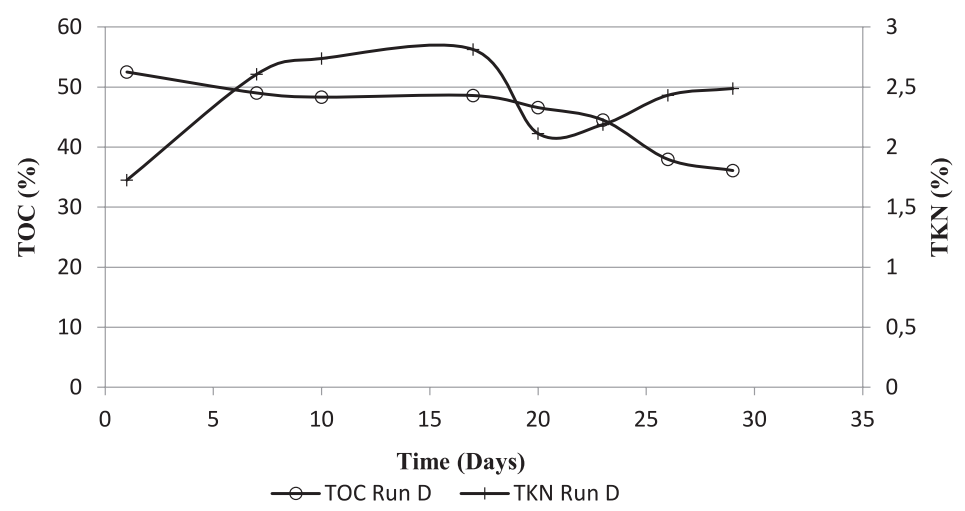

Fig. 8. TOC and TKN changes to time on Run D.

percentages as shown in Fig. 7, thereby generating a low $\mathrm{C} / \mathrm{N}$ ratio on compost yield. However, nitrogen values show a decrease in the specific observation day in this study. The reduction of nitrogen content in composting material is also associated with the loss of nitrogen in the form of ammonia $\left(\mathrm{NH}_{3}\right)$ to the environment [29-30]. However, toward the end of the process, nitrogen content was increased. This is because most of the nitrification process takes place in the mesophilic phase with a temperature between $20^{\circ} \mathrm{C}$ and $35^{\circ} \mathrm{C}$ [8].

On Run $\mathrm{D}$, the initial $\mathrm{C} / \mathrm{N}$ ratio was 30.43 with a percentage of carbon (C) $52.49 \%$ and nitrogen $(\mathrm{N})$ $1.725 \%$. Referring to Fig. 6, the $\mathrm{C} / \mathrm{N}$ ratio reduction on Run D was seen to be more stable, but there was a slight increase on days 20 and 23 , when the $\mathrm{C} / \mathrm{N}$ ratio value was 22.05 and 22.17 respectively. The previous $\mathrm{C} / \mathrm{N}$ ratio value at day 17 was 17.27 . Although the $\mathrm{C} / \mathrm{N}$ ratio increased, the value of the carbon percentage still showed a reduction. Carbon values on day 20 and 23 were recorded at $46.48 \%$ and $44.11 \%$ (Fig. 8). The increase in $\mathrm{C} / \mathrm{N}$ values was observed due to the fluctuation of nitrogen values on that day. This decline is due to the process of rotation to the rotary drum reactor that releases nitrogen through the ammonia dissipation process [31]. However, the value of the $\mathrm{C} / \mathrm{N}$ ratio starts to show a decline on day 26 , and then on the last day of composting, i.e., on day 29 the final value of $\mathrm{C} / \mathrm{N}$ obtained is 14.51 . The final carbon percentage value was $36.08 \%$ and the final nitrogen value was $2.48 \%$

Table 4 shows a univariate test for Run $\mathrm{C}$ and Run D. From the results obtained there is a significant difference in $\mathrm{C} / \mathrm{N}$ ratio to both Runs $\mathrm{C}$ and $\mathrm{D}$ with a $p$ value of $0.000(p<0.005)$ obtained and $F$ value of 24.755. The mean value of Run $C$ is 18.71 while the mean value of Run D is 19.58 . Based on the mean value obtained, the Mixture 2 (Run C) and Mixture 3 (Run D) composting processes obtained a lower $\mathrm{C} / \mathrm{N}$ ratio than Mixture 1 (Run A and Run B).

The compost obtained at Run $\mathrm{C}$ and Run D was more stable, with $\mathrm{C} / \mathrm{N}$ ratio less than 20:1. However, based on the mean value of the $\mathrm{C} / \mathrm{N}$ ratio obtained for all four runs, it can be concluded that all runs either by active aeration or without active aeration are still good and suitable for composting organic waste. However, the highest temperature that can be achieved in Run B is $45.2^{\circ} \mathrm{C}$ on day 6 of this composting. The temperature starts to decline and remains within the range of $41^{\circ} \mathrm{C}$ to $45.2^{\circ} \mathrm{C}$ for 12 days. Starting from day 15 , temperatures begin to decline to below $40^{\circ} \mathrm{C}$. In Run $\mathrm{B}$, it is seen that the composting temperature does not reach the thermophilic temperature above $45^{\circ} \mathrm{C}$.

\section{Effect of Active Aeration and Mixing Ratio on Temperature}

Natural aeration or passive aeration occurs when there is a natural blend and movement of air in the compost pile. Natural aeration is cheap, easy and does not require special equipment. Meanwhile, active aeration involves the use of equipment such as air compressors. Fig. 9 shows the change in temperature of Run A until Run D in the composting process. The data of temperature was taken daily after the composting material was added into the rotary drum. At Run A, the highest temperature reached was $55^{\circ} \mathrm{C}$ on the $10^{\text {th }}$ day of the composting process, after composting was added. Temperatures within the range $40-55^{\circ} \mathrm{C}$ remain for 24 days on the Run A composting process. On day 35 the temperature of the composting process began to show a decrease to the range of $32.1^{\circ} \mathrm{C}$ to $38.1^{\circ} \mathrm{C}$ until the end of the composting process. In the Run $\mathrm{B}$ experiment

Table 4. Univariate test analysis results for $\mathrm{C} / \mathrm{N}$ ratio on Run A and Run B.

\begin{tabular}{|c|c|c|c|c|c|}
\hline Parameter & Sum of squares & Degrees of freedom & Mean square & $F$-value & $p$-value \\
\hline Standard error of estimate & 9.109 & 1 & 9.109 & 24.755 & 0.000 \\
\hline Standard error value & 11.775 & 32 & 0.368 & & \\
\hline
\end{tabular}




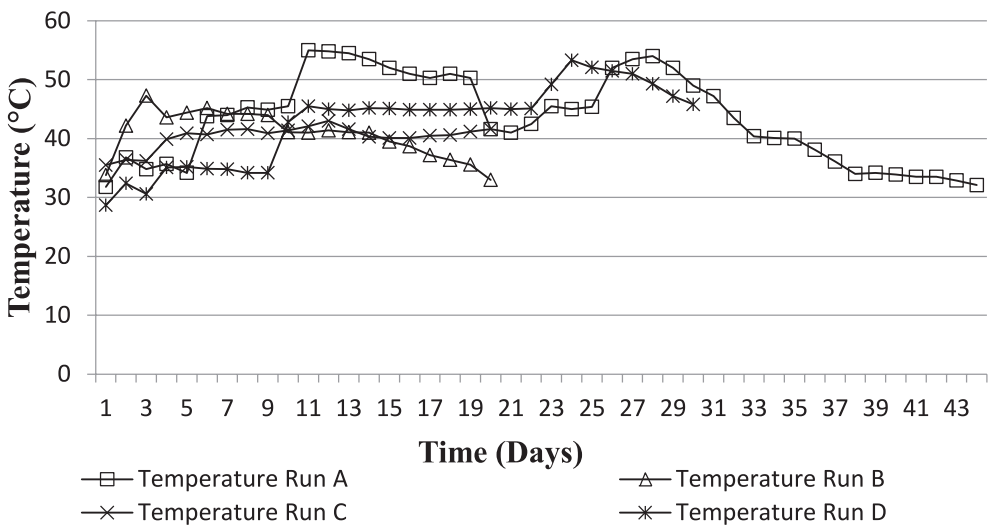

Fig. 9. Temperature profile of composting from Run A to Run D.

(with active aeration), the initial temperature of the compost material mixture was $33.8^{\circ} \mathrm{C}$. As shown in Fig. 9 , the temperature of the composting material begins to show an increase in day 2 . However, the highest temperature that can be achieved in Run B is $45.2^{\circ} \mathrm{C}$ on day 6 of this composting. The temperature starts to decline and remains within the range of $41^{\circ} \mathrm{C}$ to $45.2^{\circ} \mathrm{C}$ for 12 days. Starting from day 15 , temperatures begin to decline to below $40^{\circ} \mathrm{C}$. In Run $\mathrm{B}$, it is seen that the composting temperature does not reach the thermophilic temperature above $45^{\circ} \mathrm{C}$. Excess heat removal can be achieved through turning operations employed to control the aeration of the composting materials. The turning operation enhances the passive aeration of the composting materials by increasing air penetration into the pile [28]. By turning and active aeration in Run B, we can see that it affected the temperature arising in the composting process. For this study, passive aeration with adequate turning process is enough to supply air in the compost pile inside the drum reactor. [19] also stated that the application of passive aeration on a larger scale simultaneously permits the thermophilic temperature to be maintained during the municipal solid waste composting process and constrains microbial activity in the reactor.
Meanwhile, the initial temperature of Run $\mathrm{C}$ composting material is $32^{\circ} \mathrm{C}$. The increase in temperature on Run $\mathrm{C}$ is seen evenly, i.e., from $32^{\circ} \mathrm{C}$ (initial temperature) to $39.9^{\circ} \mathrm{C}$ on day 3 . On day 4 , the temperature starts to reach the $40^{\circ} \mathrm{C}$ range. On Run $\mathrm{C}$, the compost temperature remains in the range $40^{\circ} \mathrm{C}$ to $43^{\circ} \mathrm{C}$ (the highest temperature reached on day 11). The final day of composting, the temperature began to decline to $39.6^{\circ} \mathrm{C}$. The compost temperature of this mixture (Run C) is seen to not achieve optimum temperature of $45^{\circ} \mathrm{C}$. This may be due to a $5 \mathrm{~kg}$ mix EFB: $2.5 \mathrm{~kg}$ recycled compost: $1 \mathrm{~kg}$ of POME sludge is not an ideal mix for optimal development of microbes in a compost heap. This phenomenon agreed with [32], who found that composting temperature can also be affected by feedstock mix ratio, as feedstock ratio may relate to the initial moisture content. Fig. 10 shows the relationship between temperature and moisture content of the feedstock for all runs in this experimental process. From the scattered graph, we can conclude that higher moisture content recorded in Run 3 affected the temperature rise in the composting process. The mixture of Run A shows the highest temperature with ideal moisture content in the range of $40-50 \%$. Meanwhile, low moisture content below $35 \%$ also is not favorable

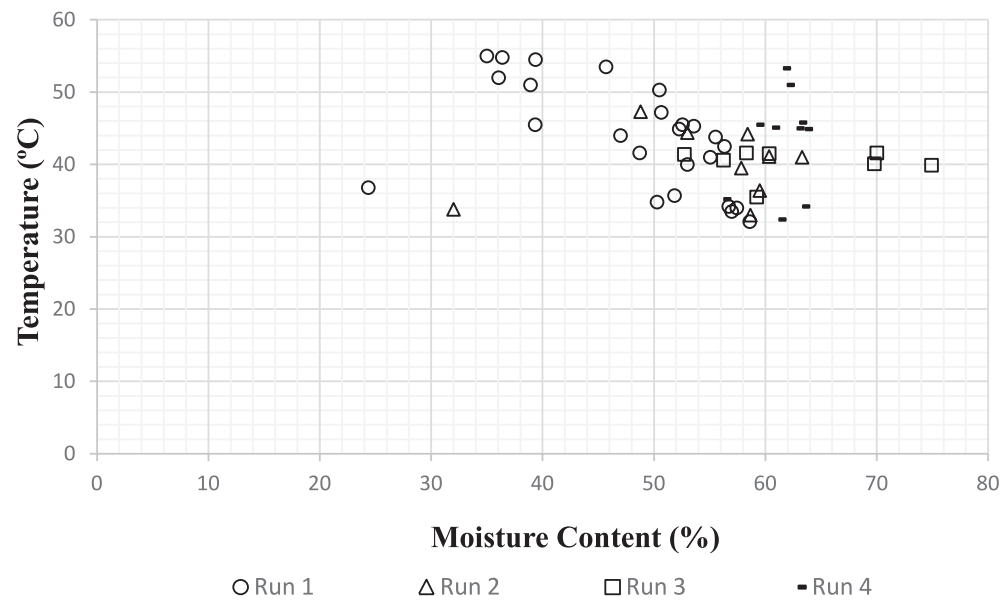

Fig. 10. Relationship between feedstock moisture content and temperature during composting process. 
in the composting process for achieving high thermophilic temperature. Hence, the most ideal moisture content for EFB and the POME sludge composting process should be upholding around 50\%.

Besides, the initial temperature of compost material mixture on Run D (Mixture 3) was $25.5^{\circ} \mathrm{C}$. The observed temperature increased gradually in this run. The temperature within the range $30^{\circ} \mathrm{C}$ lasts for 8 days at the beginning of the composting process. Starting from day 9 , the temperature starts to increase to about $40^{\circ} \mathrm{C}$ until day 22 . But on day 23 , Run D composting temperature increases to $53.3^{\circ} \mathrm{C}$. Temperatures within the range of $50^{\circ} \mathrm{C}$ to $53^{\circ} \mathrm{C}$ are seen to last for only 4 days. On the $27^{\text {th }}$ day the temperature began to decline again with a final temperature of $45.8^{\circ} \mathrm{C}$ after composting material was added. The slower rise in temperature of Run D at the beginning of composting may be attributed to an insufficient supply of a carbon source of the low $\mathrm{C} / \mathrm{N}$ ratio suggested by [28].

From the three mixtures, the mesophilic phase begins in the first 3-8 days of the composting process. The abundance of organic substances at present has encouraged the activity of microorganisms and thus generates heat energy, which causes temperature rise to occur. When temperatures rise above $45^{\circ} \mathrm{C}$, thermophilic microorganisms will dominate the compost mass [33]. On the process of composting Run C and Run D, thermophilic temperature can last only 7-9 days. Although the duration of the thermophilic phase lasts for a short period, the period is enough to destroy pathogens and parasites. According to [34], the increase in temperature in the thermophilic phase for 3-4 days is enough to destroy pathogens and parasites in compost. The decreasing temperature due to the activity of thermophilic microorganisms had subsided, and mesophilic microorganisms forwarded the decomposition process by recolonizing the substrate [8]. Stable temperature at the end of the process indicates that the decomposition rate of organic matter was reduced [35].

\section{Physical Properties of Compost Product}

Compost has great potential as a land improvement material for various uses. Composting on land in agricultural or farmland will help improve humus content, soil structure, nutrient content, water retention ability and soil aeration requirements. Currently, composting is not only limited to agricultural activities, but also extends to land reclamation activities such as quarries and landfills, erosion control, nurseries and so on. The size distribution affects the use of compost in an activity. Composting with uniform size distribution gets its place in the nursery and landscape industries, while composites with non-uniform sizes are more commonly used in erosion control activities and as cover layers at landfills. The distribution of the size is usually closely related to the product texture that affects soil productivity [22].
In this study, the size of the fiber has been determined from the beginning of the composting process until the composting process ends at each run. The average EFB fiber size distribution at the beginning of the composting process on Run A and Run B was $6.5 \mathrm{~cm}$ and $10.4 \mathrm{~cm}$ respectively, while the fiber size distribution at the beginning of the composting process for Run C and Run D was $10.4 \mathrm{~cm}$ and $13.9 \mathrm{~cm}$ respectively. On all runs, changes in the average distribution of fiber sizes were seen to decline uniformly. The sizes of EFB fiber after composting on Run A, Run B, Run C and Run D are $3.3 \mathrm{~cm}, 3.8 \mathrm{~cm}$, $3.5 \mathrm{~cm}$ and $4.7 \mathrm{~cm}$ respectively.

\section{Conclusions}

Four experimental running processes were carried out in this study. The moisture content in the four runs is within the range of $58.6-70 \%$. Final $\mathrm{C} / \mathrm{N}$ ratios for Runs A, B, C and D are 20.61, 17.54, 13.06 and 14.51 respectively. Based on the $\mathrm{C} / \mathrm{N}$ final value reading at each run, it can be concluded that the four runs in Phase 3 achieve the optimum $\mathrm{C} / \mathrm{N}$ ratio to be used as ground material. In terms of the thermophilic temperature rise and the composite mixtures of the composite material to maintain the thermophilic temperature, Run A shows the most favorable conditions compared to Runs B, C and D. Run C produces the highest moisture content because the mixed ratio used is $5 \mathrm{~kg}$ EFB: $0.5 \mathrm{~kg}$ POME sludge: $2.5 \mathrm{~kg}$ recycled compost. The use of high recycled compost on Run $\mathrm{C}$ is seen as one of the contributing factors to the high percentage of moisture content, which also affects the temperature rise of the compost heap in the drum reactor in Run $\mathrm{C}$, with the highest temperature reached being $43^{\circ} \mathrm{C}$. Therefore, to get a good composting process temperature, a mixture of organic matter plays a very important role. It can be concluded that Run $\mathrm{A}$ is the best mixture and condition without active aeration because of success in achieving thermophilic temperatures and maintaining thermophilic temperature within 20 days. Maintaining thermophilic temperature over a long period of time can help remove the pathogens and parasites in the compost product as well as it being safe to use.

\section{Acknowledgements}

The Authors would like to thank the management of Seri Ulu Langat Palm Oil Mill Factory in Dengkil, Selangor for their kind cooperation throughout our study. Thanks also to School of Civil Engineering, Universiti Sains Malaysia for providing the financial support to carried out this study. 


\section{Conflict of Interest}

The authors declare no conflict of interest.

\section{References}

1. EPSTEIN E. Basic concepts. The Science of Composting, Technomic Publishing Company, Inc, United State of America, 19, 1997.

2. OBENG L.A., WRIGHT F.W. The co composting of domestic solid and human wastes. The World Bank \& UNDP, Washington, 1987.

3. MOHAMMAD N., ALAM M.Z., KABASHI N.A., AHSAN A. Effective composting of oil palm industrial waste by filamentous fungi: A review. Resource, Conservation \& Recycling, 58, 69, 2012.

4. ZAINUDIN M.H.M., RAMLI N., HASSAN M.A., SHIRAI Y., TASHIRO K., SAKAI K., TASHIRO Y. Bacterial community shift for monitoring the co-composting of oil palm empty fruit bunch and palm oil mill effluent anaerobic sludge. J Ind Microbiol Biotechnol., 44, 869, 2017.

5. KRISHNAN Y., BONG C.P.C., AZMAN N.F., ZAKARIA Z., OTHMAN N.A., ABDULLAH N., HO C.S., LEE C.T., HANSEN S.B., HARA H. Co composting of oil palm empty fruit bunch and palm mill effluent: Microbial diversity and potential mitigation of greenhouse gas emission. Journal of Cleaner Production, 146, 94, 2017.

6. SAPARENG S., ALA A., KUSWINANTI T., RASYID B. The ability of Trichoderma S.P and Pleurotus S.P. for the decomposition of oil palm empty bunches. Pak. J. Biotechnol., 15 (2), 543, 2018.

7. NASUTION M.A., WIBAWA D.S., AHAMED T., NOGUCHI R. Selection of palm oil mill effluent treatment for biogas generation or compost production using an analytic hierarchy process. J Mater Cycles Waste Management, 20, 787, 2018.

8. DESRIHASTUT I., MUHAMAD I.I., ABDUL RAHMAN R., SAHYOGA G., GAFUR A. The effect of particle size of empty fruit bunch and ratio of biosludge of pulp and paper on biochemical changes in composting process. Jurnal Teknologi (Sciences \& Engineering) 81 (2), 81, 2019.

9. CHIN C.F.S., FURUYA Y., ZAINUDIN M.H.M, RAMLI N., HASSAN M.A., TASHIRO Y., SAKAI K. Novel multifunctional plant growth-promoting bacteria in cocompost of palm oil industry waste. Journal of Bioscience and Bioengineering, 24, 506, 2017.

10. LIM L.Y., BONG C.P.C., CHUA L.S., LEE C.T. Physicochemical profile of microbial-assisted composting on empty fruit bunches of oil palm trees. Environ Sci Pollut Res., 22, 19814, 2015.

11. SABRINA D.T., GANDAHI A.W., HANAFI M.M., MAHMUD T.M.M., NOR AZWADY A.A. Oil palm empty-fruit bunch application effects on the earthworm population and phenol contents under field conditions. African Journal of Biotechnology, 11 (19), 4396, 2012.

12. DAYANA AMIRA R., ROSHANIDA A.R., ROSLI M.I., SITI FATIMAH ZAHRAH M.F. MOHD ANUAR J., NAZRUL ADHA C.M. Bioconversion of empty fruit bunches (EFB) and palm oil mill effluent (POME) into compost using Trichoderma virens. African Journal of Biotechnology, 10 (81), 18775, 2011.
13. CHIEW Y.L., SHIMADA S. Current State and Environmental Impact Assessment for Utilizing Oil Palm Empty Fruit Bunches for Fuel, Fiber and Fertilizer A Case Study of Malaysia. Biomass and Bioenergy, 51, 109, 2013

14. NAYAK A.K., KALAMDHAD A.S. Feasibility of composting combinations of sewage sludge, cattle manure, and sawdust in a rotary drum reactor. Environ. Eng. Res., 19 (1), 47, 2014.

15. SINGH W.R., DAS A., KALAMDHAD A.S. Composting of water hyacinth using a pilot scale rotary drum composter. Environ. Eng. Res., 17 (2), 69, 2012.

16. BERNAL M.P., PAREDES C., SANCHEZ-MONEDERO M.A., ROIG A. Carbon mineralization from organic waste at different composting stages during their incubation with soil. Agr. Ecosyst. Environ., 69, 175, 1998.

17. GUO R., LI G., JIANG T., SCHUCHARDT F., CHEN T., ZHAO Y., SHEN Y. Effect of aeration rate, $\mathrm{C} / \mathrm{N}$ ratio and moisture content on the stability and maturity of compost. Bioresource Technology, 112, 171, 2012.

18. MAKAN A., ASSOBHEI O., MOUNTADAR M. Effect of initial moisture content on the in-vessel composting under air pressure of organic fraction of municipal solid waste in Morocco. Iranian Journal of Environmental Health Sciences \& Engineering, 10 (3), 2013.

19. KASINSKI S., SLOTA M., MARKOWSKI M., KAMINSKA A. Municipal waste stabilization in a reactor with an integrated active and passive aeration system. Waste Management, 50, 31, 2016.

20. SARKAR S., PAL S., SUNANDA CHANDA S. Optimization of a Vegetable Waste Composting Process with a Significant Thermophilic Phase. Procedia Environmental Sciences, 35, 435, 2016.

21. VILLASENOR J., RODRIGUEZ I., FERNANDEZ F.J. Composting domestic sewage sludge with natural zeolites in a rotary drum reactor. Bioresource Technology, 102, 1447, 2011.

22. DIAZ L.F., SAVAGE G.M., EGGERTH L.L., GOLUEKE C.G. Composting and recycling municipal solid waste. Lewis Publisher, United State of America, 1993.

23. TCHOBANOGLOUS G., THEISEN H., VIGIL S. Integrated solid waste management: Engineering Principles and Management Issues. McGraw-Hill Inc., United State of America, 1993

24. HUANG G.F., WONG J.W.C., WU Q.T., NAGAR B.B. Effect of $\mathrm{C} / \mathrm{N}$ ratio on composting of pig manure with sawdust. Waste Management, 24, 805, 2004.

25. WAHI R., YUSUP I.A. Empty fruit bunches compost and germination of Raphanus sativs L. Borneo Journal of Resource Science and Technology, 6 (1), 10, 2016.

26. GOYAL S., DHULL S.K., KAPOOR K.K. Chemical and biological changes during composting of different organic waste and assessment of compost maturity. Bioresource Technology, 82, 181, 2005.

27. WEI V.S.J., BING C.H., SAPTOROAND A., NANDONG J. Effects of temperature, aeration rate and reaction time on composting of empty fruit bunches of oil-palm. Iranica Journal of Energy and Environment, 7 (2), 156, 2016.

28. NUTONGKAEW T., DUANGSUWAN W., PRASERTSAN S., PRASERTSAN P. Physicochemical and biochemical changes during composting of different mixing ratios of biogas sludge with palm oil mill wastes and biogas effluent. Journal of Material Cycles and Waste Management, 16, 131, 2014. 
29. PARKINSON R., GIBBS P., BURCHETT S., MISSELBROOK, T. Effect of turning regime and seasonal weather conditions on nitrogen and phosphorus losses during aerobic composting. Bioresource Technology, 916, 171, 2003.

30. TIQUIA S.M., TAM N.F.Y. Co-composting of spent pig litter and sludge with forced-aeration. Bioresource Technology, 72, 1, 2000.

31. IYENGAR S.R., BHAVE P.P. In vessel composting of household wastes. Waste Management, 26 (10), 1070, 2005.

32. DELGADO-RODRIGUEZ M., RUIZ-MONTOYA M., GIRALDEZ I., LOPEZ R., MADEJON E., DIAZ M.J.
Influence of control parameters in VOCs evolution during MSW. J. Agric. Food. Chem., 59, 13035, 2011.

33. CHANG J.I., TSAI J.J., WU K.H. Thermophilic composting of food waste. Bioresource Technology, 97, 116, 2006.

34. MOHAIBES M., TANSKI H.H. Aerobic thermophilic treatment of farm slurry and food wastes. Bioresource Technology, 95, 245, 2004.

35. RAZALI W.A.W., BAHARUDDIN A.S., TALIB A.T., SULAIMAN A., NAIM M.N., HASSAN M.A., SHIRAI, Y. Degradation of oil palm empty fruit bunches (OPEFB) fiber during composting process using In-Vessel composter. Bioresource, 7 (4), 4786, 2012. 
